\title{
Phylogenetic relationships in the family Alloherpesviridae
}

\author{
Thomas B. Waltzek ${ }^{1}$, Garry O. Kelley ${ }^{1,4}$, Michael E. Alfaro ${ }^{2,5}$, Tomofumi Kurobe ${ }^{1}$, \\ Andrew J. Davison ${ }^{3}$, Ronald P. Hedrick ${ }^{1, *}$
}

${ }^{1}$ Department of Medicine and Epidemiology, School of Veterinary Medicine, University of California, Davis, California 95616, USA

${ }^{2}$ School of Biological Sciences, Washington State University, Pullman, Washington 99164, USA

${ }^{3}$ MRC Virology Unit, Institute of Virology, University of Glasgow, Church Street, Glasgow G11 5JR, UK

${ }^{4}$ Present address: California Department of Fish and Game, Fish Health Laboratory, 2111 Nimbus Road, Rancho Cordova, California 95670, USA

${ }^{5}$ Present address: Department of Ecology and Evolutionary Biology, University of California, Los Angeles, California 90095-1606, USA

\begin{abstract}
Phylogenetic relationships among herpesviruses (HVs) of mammals, birds, and reptiles have been studied extensively, whereas those among other HVs are relatively unexplored. We have reconstructed the phylogenetic relationships among 13 fish and amphibian HVs using maximum likelihood and Bayesian analyses of amino acid sequences predicted from parts of the DNA polymerase and terminase genes. The relationships among 6 of these viruses were confirmed using the partial DNA polymerase data plus the complete sequences of the terminase, helicase, and triplex protein genes; the position of these viruses among all other sequenced HVs was also investigated using the complete terminase gene. The results established the monophyly of the fish and amphibian HVs (Alloherpesviridae) separate from the HVs of mammals, birds, and reptiles (Herpesviridae) and the single recognized HV of bivalve mollusks (Malacoherpesviridae) in the order Herpesvirales. Two major clades in the family Alloherpesviridae were recognized: one consisting of viruses from cyprinid and anguillid hosts and the other of viruses from ictalurid, salmonid, acipenserid, and ranid hosts. A comparison of virus and host phylogenies suggested that closely related HVs in this family may have coevolved with their hosts, whereas significant codiversification was not apparent for the more distantly related viruses.
\end{abstract}

KEY WORDS: Alloherpesviridae $\cdot$ Fish herpesviruses $\cdot$ Frog herpesviruses $\cdot$ Phylogeny $\cdot$ Coevolution DNA polymerase $\cdot$ Terminase

Resale or republication not permitted without written consent of the publisher

\section{INTRODUCTION}

Herpesviruses (HVs) share a characteristic virion structure, which, proceeding from the center outwards, consists of a large, linear, double-stranded DNA genome, a $\mathrm{T}=16$ (triangular number) icosahedral capsid, a proteinaceous matrix (the tegument), and a host-derived lipid envelope containing viral proteins (Davison et al. 2005a). HVs infect a wide variety of vertebrate hosts, including mammals, birds, reptiles, amphibians, and fish, and at least one invertebrate group, bivalve mollusks. Complete genome sequences are currently available for 46 distinct viruses, with 41 of these infecting mammals or birds. The remaining 5 exceptions are 2 fish viruses (ictalurid HV 1, IcHV1, Davison 1992; cyprinid HV 3, CyHV3, Aoki et al. 2007), 2 frog viruses (ranid HVs 1 and 2, RaHV1 and RaHV2, Davison et al. 2006), and a bivalve mollusk virus (ostreid HV 1, OsHV1, Davison et al. 2005b).

HV taxonomy, as determined by the International Committee on Taxonomy of Viruses (www.ictvonline. org), has recently undergone a revision in which the previous family Herpesviridae was raised to an order (Herpesvirales) and split into 3 families, one (Her- 
pesviridae, divided into the subfamilies Alphaherpesvirinae, Betaherpesvirinae, and Gammaherpesvirinae) containing mammalian, avian, and reptilian viruses, one (Alloherpesviridae) containing fish and amphibian viruses, and one (Malacoherpesviridae) containing a single virus, OsHV1. The taxonomic structure of the family Herpesviridae has been well established phylogenetically, and the viruses are characterized by approximately 43 homologous genes that were presumably inherited from a common ancestor (McGeoch et al. 2006). The erection of the 2 new families was driven by the findings that these viruses are but tenuously related to the fish and amphibian HVs, which share at least 13 homologous genes with each other (Aoki et al. 2007), and that OsHV1 is related only marginally to all other HVs (Davison et al. 2005b). Indeed, the best, and perhaps only, sequence-based evidence supporting a common ancestry for all HVs resides in a single gene, that encoding the putative ATPase subunit of terminase (hereafter terminase; an enzyme complex involved in packaging DNA into capsids), in which 5 regions are conserved (Davison 1992, 2002). This protein is also conserved to a lesser extent in T4-like bacteriophages in the family Myoviridae (Davison 1992). Indeed, the perceived utilization of a similar enzyme complex for packaging DNA into preformed capsids by HVs and by members of the order Caudovirales, of which the family Myoviridae is a member (Maniloff \& Ackermann 1998), may indicate a common evolutionary origin for these viruses of animals and bacteria.

In terms of formal taxa, the family Alloherpesviridae consists of one genus (Ictalurivirus), which contains the species Ictalurid herpesvirus 1 (represented by IcHV1), and the species Cyprinid herpesvirus 3 (represented by $\mathrm{CyHV3),} \mathrm{which} \mathrm{has} \mathrm{not} \mathrm{been} \mathrm{assigned} \mathrm{to} \mathrm{a} \mathrm{genus}$ (www.ictvonline.org). It also contains several fish and amphibian viruses that have not been assigned to any taxa: acipenserid HV 1 (AciHV1), acipenserid HV 2 (AciHV2), anguillid HV 1 (AngHV1), cyprinid HV 1 (CyHV1), and cyprinid HV 2 (CyHV2), esocid HV 1 (EsHV1), percid HV 1 (PeHV1), pleuronectid HV 1 (PlHV1), RaHV1, RaHV2, and salmonid HV 1 (SalHV1), and salmonid HV 2 (SalHV2) (Davison et al. 2005a). Thus, the classification of viruses in the family Alloherpesviridae is at an early stage. Nonetheless, HVs are well represented in freshwater and marine fishes (Wolf 1988, Hedrick \& Sano 1989, Hetrick \& Hedrick 1993), and the 2 known amphibian HVs (RaHV1 and RaHV2) were isolated from a single species, Rana pipiens, the leopard frog. Table 1 presents a comprehensive list of recognized fish and amphibian HVs with a summary of their features. The biology of these viruses has been examined in less detail than that of members of the family Herpesviridae, but the 2 groups share similar general characteristics, including narrow host specificity and establishment of long-term (perhaps latent) infections. Most fish HVs are epitheliotropic, inducing changes such as hypertrophy, hyperplasia, and necrosis of the epidermis, and, in some cases, neoplasia (Sano et al. 1985a). They can induce diseases ranging from mild subclinical infections in mature fish to severe systemic infections and mortality in young or immunologically naïve fish (Hedrick \& Sano 1989).

Genetic relationships among fish and amphibian HVs have been examined in several studies. Two short sequences obtained from SalHV2 share similarities to IcHV1 genes (Bernard \& Mercier 1993) and are more closely related to the corresponding genes in SalHV1 (Davison 1998). Sequence data sampled across the SalHV1 genome revealed at least 18 genes with homologs in IcHV1 (Davison 1998). Sequence comparisons of 5 genes showed that CyHV1, CyHV2, and CyHV3 are related closely to each other and more distantly to IcHV1 and RaHV1 (Waltzek et al. 2005). Comparisons of complete genome sequences demonstrated that RaHV1 and RaHV2 have 40 convincingly conserved genes, 19 of which have homologs in IcHV1 (Davison et al. 2006). IcHV1 and CyHV3 have 15 homologs (Aoki et al. 2007).

Although these studies were instrumental in the taxonomical restructuring described above, analysis of sequence data from a greater number of viruses is required to confirm the monophyly of the family Alloherpesviridae and to facilitate future taxonomical developments. The present study involved the generation of a molecular dataset consisting of partial sequences encoding conserved regions of DNA polymerase and terminase for $9 \mathrm{HVs}$ from 5 families of fish (Acipenseridae, Cyprinidae, Anguillidae, Salmonidae, and Ictaluridae) and complete sequences encoding the terminase, helicase, and a putative intercapsomeric triplex protein (hereafter triplex protein) of CyHV2, and the terminase of CyHV1. When combined with published information, these data facilitated an evaluation of the evolutionary branching patterns of a total of 13 fish and amphibian HVs and an examination of concordance between virus and host phylogeny.

\section{MATERIALS AND METHODS}

Virus purification. Isolate and source information for the fish and amphibian HVs used in the present study are presented in Table 2. Our studies were restricted to those fish HVs where adequate infected tissue was available or propagation in fish cell lines was possible. The fish HVs marked in Table 1 were grown in the appropriate permissive cell lines until cytopathic effect 
Table 1. Recognized fish and amphibian herpesviruses (HVs). Cell line abbreviations are EK: eel kidney; EP: eel epidermis; KF: koi fin; GF: goldfish fin; CCO: channel catfish ovary; WSS: white sturgeon spleen; RTG: rainbow trout gonad; CHSE: Chinook salmon embryo; ICR: leopard frog embryo; WO: walleye ovary. EM: virus observed using electron microscopy but not isolated in cell culture and thus unavailable for analysis in the present study (except SalHV3)

\begin{tabular}{|c|c|c|c|c|}
\hline $\begin{array}{l}\text { Virus name } \\
\text { (virus abbreviation) }\end{array}$ & Common name (abbreviation) & Host(s) & Cell line & Source \\
\hline $\begin{array}{l}\text { Cyprinid HV } 1 \\
\text { (CyHV1) }^{\mathrm{a}}\end{array}$ & $\begin{array}{l}\text { HV cyprini, carp pox HV, carp HV } \\
\text { (CHV) }\end{array}$ & Common carp Cyprinus carpio & KF-1 & Sano et al. (1985b) \\
\hline $\begin{array}{l}\text { Cyprinid HV } 3 \\
\text { (CyHV3) }^{\mathrm{d}}\end{array}$ & $\begin{array}{l}\text { Koi HV (KHV), carp nephritis and gill } \\
\text { necrosis virus (CNGV) }\end{array}$ & Common carp Cyprinus carpio & KF-1 & Hedrick et al. (2000) \\
\hline $\begin{array}{l}\text { Ictalurid HV } 1 \\
\text { (IcHV1) }^{\mathrm{d}}\end{array}$ & Channel catfish virus (CCV) & Channel catfish Ictalurus punctatus & $\mathrm{CCO}$ & Fijan et al. (1970) \\
\hline $\begin{array}{l}\text { Ictalurid HV } 2 \\
\text { (IcHV2) }^{\mathrm{a}, \mathrm{c}}\end{array}$ & Ictalurus melas HV (IcmHV) & $\begin{array}{l}\text { Black bullhead Ameiurus melas and } \\
\text { channel catfish Ictalurus punctatus }\end{array}$ & $\mathrm{CCO}$ & Hedrick et al. (2003) \\
\hline $\begin{array}{l}\text { Acipenserid HV } 2 \\
\text { (AciHV2) }^{\mathrm{a}}\end{array}$ & White sturgeon HV 2 & $\begin{array}{l}\text { White sturgeon Acipenser transmon- } \\
\text { tanus }\end{array}$ & WSS-1 & Watson et al. (1995) \\
\hline $\begin{array}{l}\text { Salmonid HV } 1 \\
\text { (SalHV1) }^{\mathrm{a}}\end{array}$ & $\begin{array}{l}\text { HV salmonis (HPV) } \\
\text { Steelhead herpesvirus (SHV) }\end{array}$ & $\begin{array}{l}\text { Rainbow trout Oncorhynchus mykiss } \\
\text { Rainbow trout Oncorhynchus mykiss }\end{array}$ & $\begin{array}{l}\text { RTG-2 } \\
\text { CHSE }\end{array}$ & $\begin{array}{l}\text { Wolf \& Taylor (1975) } \\
\text { Eaton et al. (1989) }\end{array}$ \\
\hline $\begin{array}{l}\text { Salmonid HV } 2 \\
\text { (SalHV2) }^{\mathrm{a}}\end{array}$ & $\begin{array}{l}\text { Oncorhynchus masou virus (OMV) } \\
\text { Yamame tumor virus (YTV) }^{\mathrm{a}} \\
\text { Oncorhynchus kisutch virus (OKV) } \\
\text { Coho salmon tumor virus (COTV) } \\
\text { Coho salmon HV (CSH) } \\
\text { Rainbow trout kidney HV (RKV) } \\
\text { Nerka Virus in Towanda Lake, Akita } \\
\text { and Aomori Prefecture (NeVTA) }^{\mathrm{a}}\end{array}$ & $\begin{array}{l}\text { Cherry salmon Oncorhynchus masou } \\
\text { Cherry salmon Oncorhynchus masou } \\
\text { Coho salmon Oncorhynchus kisutch } \\
\text { Coho salmon Oncorhynchus kisutch } \\
\text { Coho salmon Oncorhynchus kisutch } \\
\text { Rainbow trout Oncorhynchus mykiss } \\
\text { Sockeye salmon Oncorhynchus nerka }\end{array}$ & $\begin{array}{l}\text { RTG } \\
\text { RTG } \\
\text { RTG } \\
\text { RTG } \\
\text { RTG } \\
\text { CHSE } \\
\text { RTG }\end{array}$ & $\begin{array}{l}\text { Kimura et al. (1981) } \\
\text { Sano et al. (1983) } \\
\text { Horiuchi et al. (1989) } \\
\text { Kimura \& Yoshimizu (1991) } \\
\text { Kumagai et al. (1994) } \\
\text { Suzuki (1993) } \\
\text { Sano (1976) }\end{array}$ \\
\hline $\begin{array}{l}\text { Salmonid HV } 3 \\
\text { (SalHV3) })^{\mathrm{c}, \mathrm{d}}\end{array}$ & $\begin{array}{l}\text { Epizootic epitheliotropic disease virus } \\
\text { (EEDV) }\end{array}$ & Lake trout Salvelinus namaycush & EM & $\begin{array}{l}\text { McAllister \& Herman } \\
\text { (1989), Bradley et al. (1989) }\end{array}$ \\
\hline $\begin{array}{l}\text { Esocid HV } 1 \\
\text { (EsHV1) }\end{array}$ & $\begin{array}{l}\text { Pike epidermal proliferative } H V \text {, pike } \\
\text { HV }\end{array}$ & $\begin{array}{l}\text { Northern pike Esox lucius and muskel- } \\
\text { lunge E. masquinongy }\end{array}$ & EM & Yamamoto et al. (1983) \\
\hline $\begin{array}{l}\text { Pleuronectid HV } 1 \\
\text { (PlHV1) }\end{array}$ & HV scopthalami & Turbot Scopthalamus maximus & EM & $\begin{array}{l}\text { Buchanan \& Madeley } \\
\text { (1978) }\end{array}$ \\
\hline None & Flounder HV (FHV) & $\begin{array}{l}\text { Japanese flounder Paralichthys } \\
\text { olivaceous }\end{array}$ & EM & Iida et al. (1989) \\
\hline None & Golden ide virus & Golden ide Leuciscus ide & EM & McAllister et al. (1985) \\
\hline None & Pacific cod HV & Pacific cod Gadus macrocephalus & EM & McArn et al. (1978) \\
\hline None & Sheatfish HV (SHV) & Wels Silurus glanis & EM & Békesi et al. (1981) \\
\hline None & Smelt papillomatous virus & European smelt Osmerus eperlanus & EM & Anders \& Moller (1985) \\
\hline None & None & Rainbow smelt Osmerus mordax & EM & Morrison et al. (1996) \\
\hline None & Smooth dogfish HV & Smooth dogfish Mustelus canis & EM & Leibovitz \& Leibovitz (1985) \\
\hline None & Atlantic salmon papillomatosis virus & Atlantic salmon Salmo salar & EM & Schelkunov et al. (1992) \\
\hline None & Angelfish HV & Angelfish Pterophyllum altum & EM & Mellergard \& Bloch (1988) \\
\hline None & Pilchard HV & Pacific sardine Sardinops sagax & EM & Hyatt et al. (1997) \\
\hline None & None & Red striped rockfish Sebastes proriger & EM & Kent \& Meyers (2000) \\
\hline
\end{tabular}

${ }^{a}$ Viruses isolated in cell culture, purified, and analyzed in the present study. ${ }^{b}$ Virus has been isolated in cell culture but material was not available for analysis in the present study. ${ }^{\mathrm{C}}$ Tentative designation. ${ }^{\mathrm{d}}$ Analyzed but not isolated in the present study 


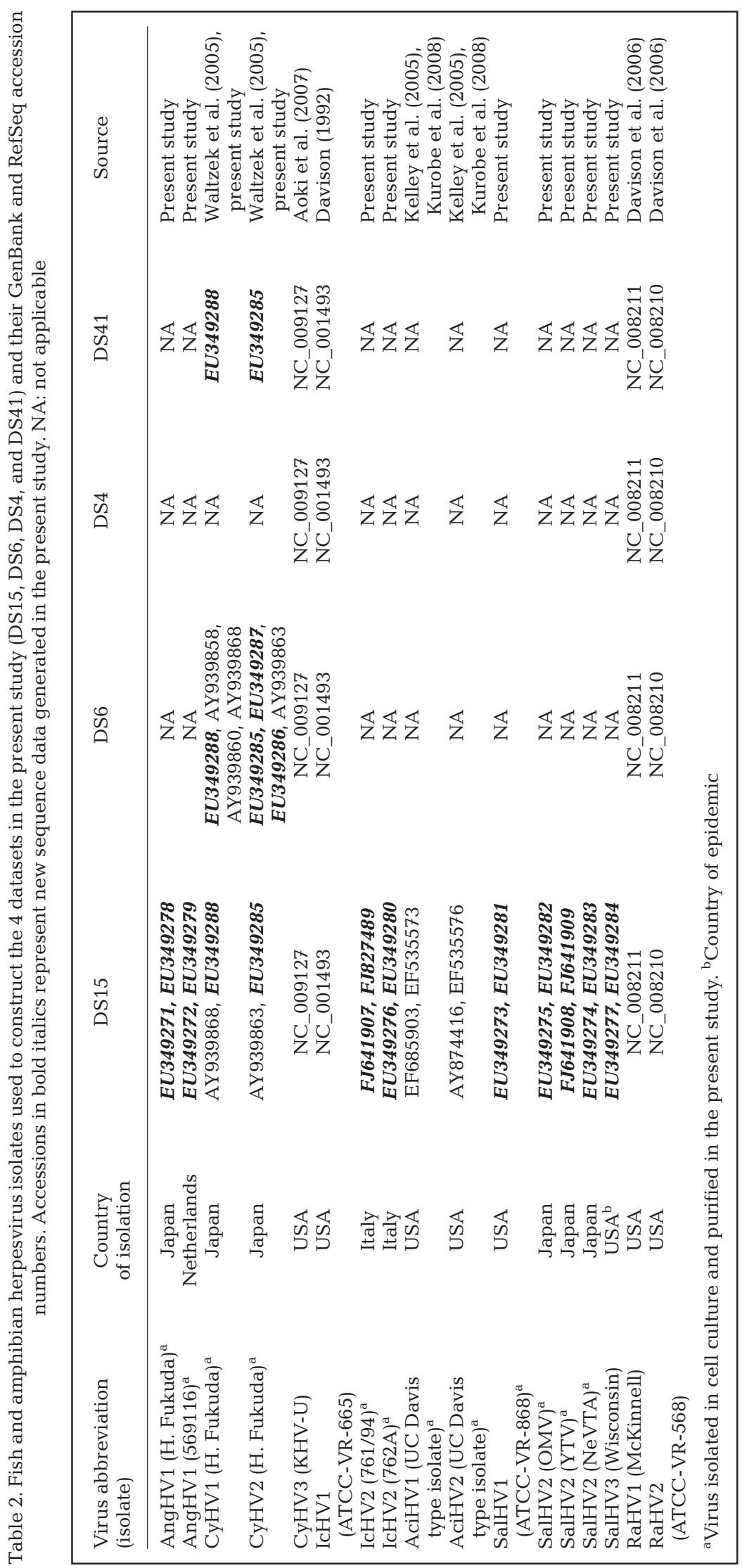

was complete. All except salmonid HV 3 (SalHV3) were purified before viral genomic DNA was isolated, as described previously (Waltzek et al. 2005). For SalHV3, DNA was extracted from infected skin tissues using a DNeasy kit (QIAGEN), following the tissue extraction protocol. DNA was stored at $4^{\circ} \mathrm{C}$.

Previous sequence data. The analysis focused on 4 conserved genes encoding DNA polymerase (ORF57 in IcHV1), terminase (ORF62, present as 3 coding exons), helicase (ORF25), and triplex protein (ORF27). For IcHV1, RaHV1, RaHV2, and CyHV3, the complete sequences of these, and other, genes were derived from the published genome sequences (Davison 1992, Davison et al. 2006, Aoki et al. 2007). The complete DNA polymerase, helicase, and triplex protein sequences were available for CyHV1, and partial sequences were available for CyHV2 (Waltzek et al. 2005). Sequence data for mollusk, avian, and mammalian HVs, and T4-like bacteriophages were obtained from RefSeq (www. ncbi.nlm.nih.gov/genomes/VIRUSES/ 35237.html); accession numbers and references are listed in Table 3.

New sequence data. Details on the primers and the viruses from which sequences were amplified are given in Table 4. A pair of degenerate primers, $\mathrm{HV}$ and cons lower (Hanson et al. 2006), was used to amplify a 441 to $474 \mathrm{bp}$ fragment (primer binding sites excluded) of the DNA polymerase gene, and 5 conserved primer pairs were designed on the basis of alignments to amplify regions of the terminase gene. Although amplicon sizes varied between the terminase primer sets, all amplicons contained a common 315 to $330 \mathrm{bp}$ sequence located in the third region of conservation of the terminase gene (Davison 2002), and this was used for phylogenetic analyses. The PCR conditions for all primer sets were those used previously (Kelley et al. 2005). Amplicons were purified from $10 \mu \mathrm{l}$ of the PCR products by excision from an agarose gel and cloned using a TOPA TA Cloning Kit (Invitrogen). 
Table 3. RefSeq accession numbers for the sequences representing species in the family Herpeviridae from mammalian, avian, and oyster herpesviruses (HVs) and T4-like bacteriophages used to construct Dataset 41 (DS41)

\begin{tabular}{|c|c|}
\hline Species name (Virus abbreviation) & RefSeq \\
\hline Alcelaphine herpesvirus 1 (AlHV1) & NC_002531 \\
\hline Ateline herpesvirus 3 (AtHV3) & NC_001987 \\
\hline Bovine herpesvirus 1 (BoHV1) & NC_001847 \\
\hline Bovine herpesvirus 4 (BoHV4) & NC_002665 \\
\hline Bovine herpesvirus 5 (BoHV5) & NC_005261 \\
\hline Ceropithecine herpesvirus 2 (CeHV2) & NC_006560 \\
\hline Ceropithecine herpesvirus 9 (CeHV9) & NC_002686 \\
\hline Equid herpesvirus 1 (EHV1) & NC_001491 \\
\hline Equid herpesvirus 4 (EHV4) & NC_001844 \\
\hline Human herpesvirus 1 (HHV1) & NC_001806 \\
\hline Human herpesvirus 2 (HHV2) & NC_001798 \\
\hline Human herpesvirus 3 (HHV3) & NC_001348 \\
\hline Human herpesvirus 4 (HHV4) & NC_001345 \\
\hline Human herpesvirus 5 (HHV5) & NC_006273 \\
\hline Human herpesvirus 6 (HHV6) & NC_001664 \\
\hline Human herpesvirus 7 (HHV7) & NC_001716 \\
\hline Human herpesvirus 8 (HHV8) & NC_003409 \\
\hline Gallid herpesvirus 1 (GaHV1) & NC_006623 \\
\hline Gallid herpesvirus 2 (GaHV2) & NC_002229 \\
\hline Gallid herpesvirus 3 (GaHV3) & NC_002577 \\
\hline Macacine herpesvirus 1 (McHV1) & NC_004812 \\
\hline Macacine herpesvirus 4 (McHV4) & NC_006146 \\
\hline Macacine herpesvirus 8 (McHV8) & NC_006150 \\
\hline Meleagrid herpesvirus 1 (MeHV1) & NC_002641 \\
\hline Murid herpesvirus 2 (MuHV2) & NC_002512 \\
\hline Murid herpesvirus 4 (MuHV4) & NC_001826 \\
\hline Ovine herpesvirus 2 (OvHV2) & NC_007646 \\
\hline Ostreid herpesvirus 1 (OsHV1) & NC_005881 \\
\hline Panine herpesvirus 2 (PaHV2) & NC_003521 \\
\hline Psittacid herpesvirus 1 (PsHV1) & NC_005264 \\
\hline Saimiriine herpesvirus 2 (SaHV2) & NC_001350 \\
\hline Suid herpesvirus 1 (SuHV1) & NC_006151 \\
\hline Tupaiid herpesvirus 1 (TuHV1) & NC_002794 \\
\hline T4 bacteriophage (T4) & NC_000866 \\
\hline RB 69 bacteriophage (RB69) & NC_004928 \\
\hline
\end{tabular}

Transformed bacterial colonies were screened using PCR, and plasmids containing relevant inserts were purified using a QIAprep Spin Miniprep Kit (QIAGEN). For each amplicon, 2 purified plasmid clones were sequenced using M13 forward and reverse primers with an ABI 377 automated sequencer (Applied Biosystems).

The complete CyHV2 helicase, triplex protein, and terminase sequences were derived from PCR, RT-PCR, and Rapid Amplification of cDNA Ends (RACE) experiments, employing primers designed from alignments of the relevant CyHV3 and CyHV1 data. Briefly, total RNA was isolated from a CyHV2-infected goldfish fin cell line (GF-1) using TRIZOL (Invitrogen), and $500 \mathrm{ng}$ was transcribed into cDNA using a BD SMART RACE cDNA amplification kit (BD Biosciences). Using RNA or cDNA and primers listed in Table 4, PCR, RT-PCR, and RACE were performed with an initial denaturation step of $95^{\circ} \mathrm{C}$ for $5 \mathrm{~min}, 30$ cycles of $95^{\circ} \mathrm{C}$ for $30 \mathrm{~s}, 55^{\circ} \mathrm{C}$ for $30 \mathrm{~s}$, and $72^{\circ} \mathrm{C}$ for $2 \mathrm{~min}$, and a final extension step at $72^{\circ} \mathrm{C}$ for $5 \mathrm{~min}$. The reactions were held at $4^{\circ} \mathrm{C}$. The amplicons were cloned and sequenced as described above.

The 3'-RACE using primer CyHV2HelF and the BD SMART nested universal primer (NUP) yielded a 1996 bp amplicon. When analysed by BLASTP searches of GenBank databases, the sequence revealed the presence of both the 3'-end of the CyHV2 helicase gene and the complete triplex protein sequence, presumably as a result of their presence on the same mRNA. The 5'-RACE using primer CyHV2HelRACER1 and NUP yielded a 586 bp amplicon. The combined data from 5'- and 3'-RACE yielded a total of $2441 \mathrm{bp}$ of sequence containing the complete CyHV2 helicase and triplex protein coding regions.

PCR using primers 161 and 162 yielded a 595 bp amplicon in Exon 1 of the CyHV2 terminase gene. The remainder of Exon 1, Exon 2, and the 5'-end of Exon 3 was amplified by RT-PCR using primers 155 and 118, which yielded a $1062 \mathrm{bp}$ amplicon. PCR using primers 96 and 99 amplified a $721 \mathrm{bp}$ sequence that extended Exon 3. Finally, 3'-RACE using primer 121 and NUP yielded an $864 \mathrm{bp}$ amplicon containing the 3 '-end of Exon 3. When combined, these data yielded $2628 \mathrm{bp}$ of sequence containing the complete CyHV2 terminase coding region. For $\mathrm{CyHV1}$, the complete terminase sequence was recovered from an incomplete shotgun sequence database (A. J. Davison \& R. P. Hedrick unpubl. data).

Establishment of datasets. Table 2 summarizes the HVs, genes, and corresponding GenBank and/or RefSeq accession numbers used to generate the 4 datasets used for phenetic and phylogenetic analyses. BLASTP searches of GenBank databases using the DNA polymerase and terminase sequences were performed in order to acquire appropriate outgroups. Both partial gene sets revealed strongest similarity with other fish and amphibian HVs. Additionally, the terminase set revealed substantial but lower similarity with other HVs, and, at a lower level, with several T4-like bacteriophages. The DNA polymerase search yielded but marginal similarity with other HVs (see Table 5), thus making the choice of outgroups challenging. This is consistent with previous work indicating that the DNA polymerases of fish HVs are distinct from those of mammalian HVs (Knopf 1998). As a result of these preliminary analyses, 4 operational datasets were established.

Dataset 15 (DS15) contained 309 amino acid (AA) characters (including gaps) and consisted of the concatenated partial DNA polymerase and terminase sequences for 13 fish and amphibian HVs plus, as selected outgroups, 2 mammalian HVs, human HV 8 


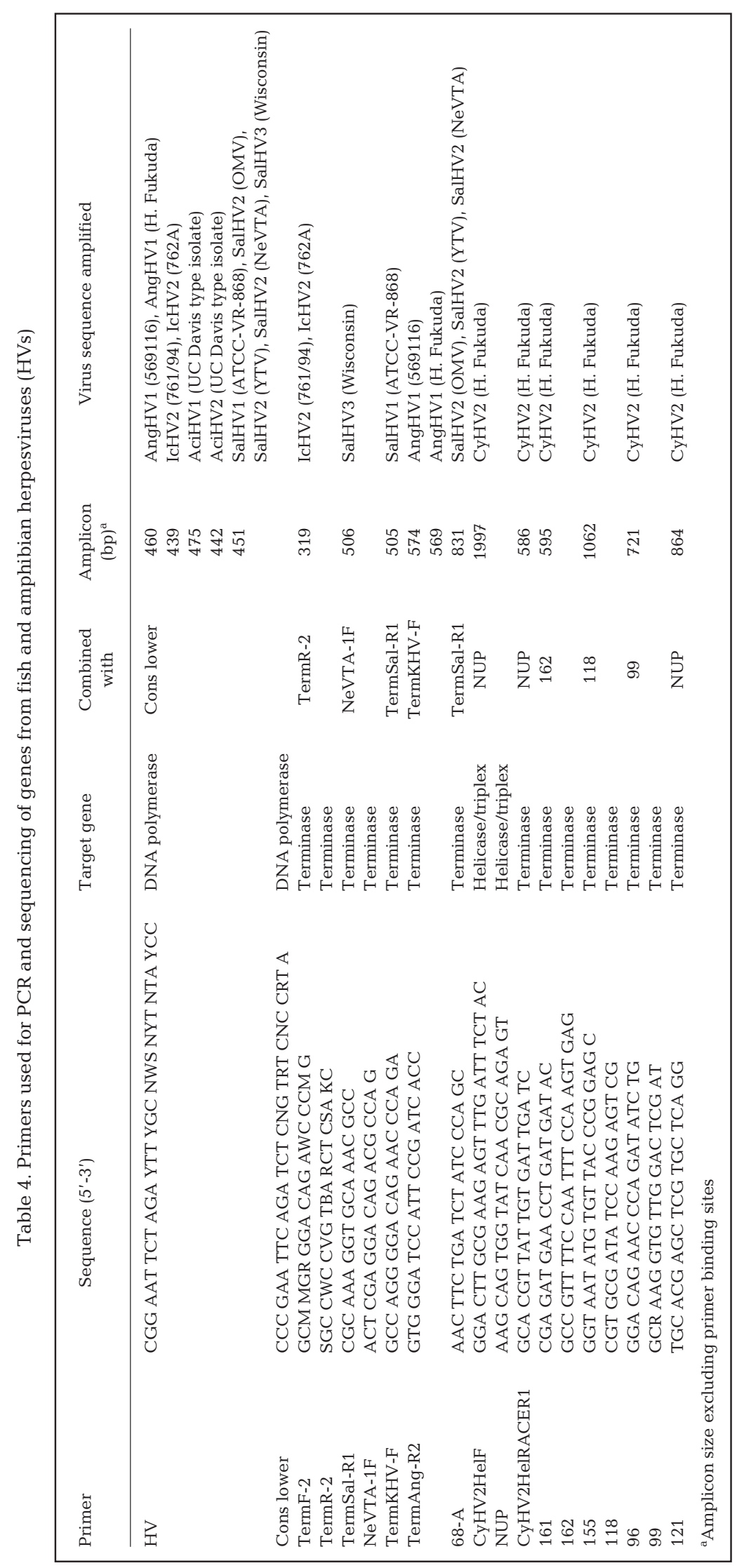

(HHV8) from the subfamily Gammaherpesvirinae, and human HV 1 (HHV1) from the subfamily Alphaherpesvirinae in the family Herpesviridae. The individual genes were first analyzed separately to facilitate comparison with the concatenated analysis.

Dataset 6 (DS6) contained 2356 AA characters (including gaps) and consisted of a concatenation of the complete terminase, helicase, and triplex protein sequences plus the partial DNA polymerase sequence for 6 fish and amphibian HVs. DS6, being based on longer sequences, was utilized to strengthen aspects of the DS15 analysis. As an initial step, the individual gene sequences were analyzed separately in order to facilitate comparison with the concatenated analysis.

Dataset 4 (DS4) contained 13747 AA characters (including gaps) and consisted of a concatenation of the $13 \mathrm{com}$ plete genes that are convincingly conserved among the 4 sequenced fish and amphibian HVs (Aoki et al. 2007). The genes in IcHV1 (and putative characteristics or functions) are ORF25 (helicase), ORF27 (triplex protein), ORF28 (protease), ORF37 (unknown), ORF39 (major capsid protein), ORF46 (glycoprotein), ORF54 (unknown), ORF56 (unknown), ORF57 (DNA polymerase), ORF60 (unknown), ORF62 (terminase), ORF63 (primase), and ORF64 (unknown).

Dataset 41 (DS41) contained 283 AA characters (including gaps) and consisted of a concatenation of the 5 conserved regions of terminase (trimmed in the fifth region to the last conserved residue; Davison 2002) for 6 fish and amphibian HVs and 33 other HVs, plus 2 T4-like bacteriophages as outgroups. Viruses in the family Herpesviridae were limited to those for which complete genome sequences were available.

Phylogenetic analysis. AA sequences were aligned using MAFFT 5.8 (Katoh et al. 2005) followed by minor manual adjustments using ClustalW (Thompson et al. 1994). The E-INS-i alignment strategy was used with the following parameters: scoring matrix (BLOSUM62), gap open penalty (1.53), and offset value (0). 
To assess gene concordance, likelihood (TREEPUZZLE 5.2; Schmidt et al. 2002) and Bayesian (MrBayes version 3.1.2; Huelsenbeck \& Ronquist 2001) analyses were performed independently for each gene. Preliminary analysis revealed that there was no significant incongruency among individual gene trees (defined by the presence of incompatible bipartitions that received a quartet puzzling probability $>80 \%$ or a posterior probability $>90 \%$ ). Phylogenetic trees were constructed in TREEVIEW (Page 1996) or PAUP* (Swofford 2001). TREE-PUZZLE 5.2 was utilized to select the most appropriate model of AA sequence evolution for subsequent likelihood analysis. Statistical confidence of tree topologies was assessed using 1000 puzzling steps for quartet puzzling trees, and all other settings were default. For Bayesian analysis, a mixed prior was used on AA models and default priors for topology (uniform) and branch lengths (Exp 10). The Markov chain was run for a maximum of 10 million generations, with a stopping rule implemented so that the analysis would halt when the average deviation of the split frequencies became $<0.001 \%$. Four independent analyses were conducted, each with 1 cold and 3 heated chains with the default heating parameter (temp $=0.2$ ). Sampling occurred every 50 generations with the first $25 \%$ of Markov chain Monte Carlo (MCMC) samples discarded as burn-in.

To test whether fish and amphibian HVs show a significant pattern of codiversification with their hosts, a host-parasite tanglegram (Page \& Hafner 1996, Page \& Charleston 1998) was produced using TreeMap 2.0, Hughes et al. (2007). The fish host topology (Helfman et al. 1997) was compared with the Bayesian consensus tree of the HVs. The randomization test implemented in TreeMap was used with 1000 replicates to generate the null distribution for the expected number of codiversification events.

\section{RESULTS}

The DS15 analysis demonstrated the monophyly of the 13 fish and amphibian HVs tested (Fig. 1). The DS6 and DS4 analyses (Figs. 2 \& 3, respectively), which were based on longer sequences, produced a concordant phylogeny for a subset of these viruses. The more restricted DS41 analysis of this subset of viruses (Fig. 4) reiterated their monophyly, and also accorded the family Herpesviridae an overall taxonomic arrangement very similar to that established previously using much longer sequences (McGeoch et al. 1995, 2000, 2005, 2006). A third, monotypic group was formed by OsHV1 (Malacoherpesviridae).

Two major sister clades were evident in the family Alloherpesviridae: Clade 1, comprising HVs of cypri- nid and anguillid origin, and Clade 2, comprising those from ranid, acipenserid, salmonid, and ictalurid hosts (Fig. 1). In Clade 1, the monophyly of the cyprinid HVs was supported by all analyses, with CyHV2 and CyHV3 most closely related and CyHV1 their sister group. The DS15 analysis (Fig. 1) supported AngHV1 as the sister group to the cyprinid HVs. At a more detailed level, the sequence of the DNA polymerase gene fragment of AngHV1 was identical in Dutch and Japanese isolates (Table 5), and also identical to previously reported sequences from Dutch and Japanese isolates (Rijsewijk et al. 2005). Moreover, it was 99\% identical to an isolate from Japanese eels in Taiwan (Chang et al. 2002), exhibiting one synonymous and one non-synonymous difference. Two synonymous differences and 5 insertions or deletions characterized the terminase gene fragment of the Dutch and Japanese isolates. However, these isolates exhibited identical AA sequences for the smaller terminase region analyzed. Since the DNA polymerase and terminase gene fragments were identical among the Dutch and Japanese AngHV1 isolates for the regions analyzed in the present study, they are represented collectively as AngHV1 in Figs. 1, 5 \& 6 .

The monophyly of Clade 2, which contains HVs from ranid, acipenserid, salmonid, and ictalurid hosts, was supported by the DS15 analysis (Fig. 1). A subset of this clade consisting of IcHV1, RaHV1, and RaHV2 was also monophyletic in the DS41 analysis (Fig. 4). Within this subset, IcHV1 and IcHV2 were sister viruses and AciHV2 their closest relative (Fig. 1). At a more detailed level, the 761/94 and 762A isolates of IcHV2 exhibited identical nucleotide sequences for the regions of the DNA polymerase and terminase genes analyzed. Thus, they are represented collectively as IcHV2 in Figs. 1, 5 \& 6. The monophyly of the sister group to this subset was strongly supported, with SalHV1 and SalHV2 as sister viruses and SalHV3 their nearest relative (Fig. 1). The OMV, YTV, and NeVTA isolates of SalHV2 exhibited identical nucleotide sequences for the regions of the DNA polymerase and terminase genes analyzed. Thus, they are represented collectively as SalHV2 in Figs. 1, 5 \& 6. The partial DNA polymerase and terminase sequences for AciHV1 and AciHV2 (standard UC Davis strains) were identical to those deposited previously in GenBank (Kelley et al. 2005, Kurobe et al. 2008). AciHV1 was the next most closely related virus to the ictalurid and salmonid HV clades (Fig. 1). A strongly supported subset consisting of RaHV1 and RaHV2 formed the sister group to the rest of the viruses in Clade 2 (Figs. 1 to 4). The DS4 analysis supported a somewhat closer relationship between the ranid and ictalurid HVs than between viruses in either group and the cyprinid HVs (Fig. 3). 
Fig. 1. Phylogram depicting relationships among fish and amphibian herpesviruses (HVs), based on the concatenated partial deduced amino acid (AA) sequences of the DNA polymerase and terminase genes (Dataset 15, 309 AA characters including gaps). The quartet puzzling maximum likelihood tree was rooted with 2 mammalian HVs (HHV1 and HHV8). Numbers above each node represent quartet puzzling probabilities (values $>80$ shown) of the maximum likelihood analysis; numbers below represent posterior probabilities (values >90 shown) of the Bayesian analysis. Branch lengths are based on the number of inferred substitutions, as indicated by the scale bar
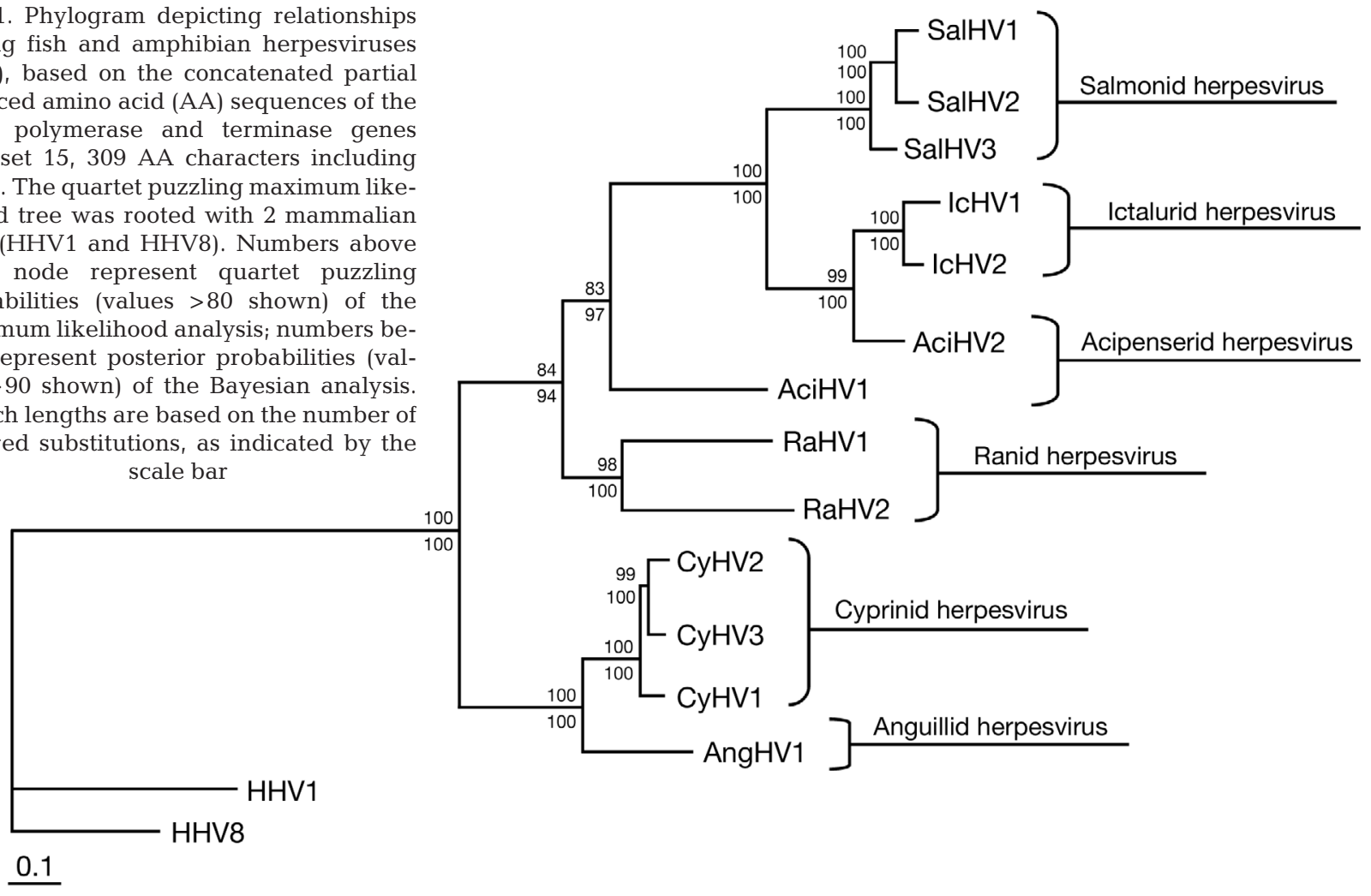

The host-virus tanglegram (Fig. 5) revealed strong overall discordance between HV and host lineages, with a randomization test revealing no significant support for codiversification $(p=0.61)$.

\section{DISCUSSION}

The utility of partial sequence analyses has been established previously in resolving the evolutionary

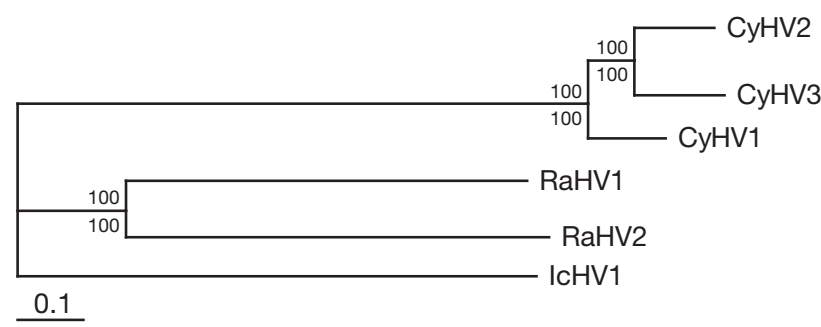

Fig. 2. Phylogram depicting relationships among fish and amphibian herpesviruses (HVs), based on the concatenated deduced amino acid (AA) sequences of the full length terminase, helicase, and triplex protein genes, plus the partial DNA polymerase gene (Dataset 6, 2356 AA characters including gaps). The tree is not rooted. Numbers above each node represent quartet puzzling probabilities (values $>80$ shown) of the maximum likelihood analysis; numbers below represent posterior probabilities (values $>90$ shown) of the Bayesian analysis. Branch lengths are based on the number of inferred substitutions, as indicated by the scale bar. See Table 1 for abbreviations relationships among HVs of mammals (Ehlers et al. 1999, Ehlers \& Lowden 2004, Wibbelt et al. 2007) and reptiles (McGeoch \& Gatherer 2005), and is extended in the present study to fish and amphibian HVs. Phylogenetic analyses of partial sequences from the DNA polymerase and terminase genes, and of more extensive sequences for a subset of viruses, strongly support the monophyly of fish and amphibian HVs within a larger clade containing all HVs. In addition, analysis of the terminase, which is unique to the HVs and the

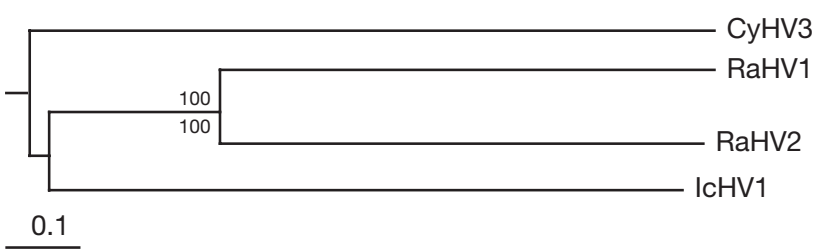

Fig. 3. Phylogram depicting relationships among fish and amphibian herpesviruses (HVs), based on the concatenated deduced amino acid (AA) sequences of the 13 full-length genes conserved among completely sequenced genomes (Dataset 4, 13747 AA characters including gaps). The maximum likelihood tree was rooted using the midpoint rooting feature in PAUP* ${ }^{*}$ Numbers above each node represent quartet puzzling probabilities (values $>80$ shown) of the maximum likelihood analysis; numbers below represent posterior probabilities (values >90 shown) of the Bayesian analysis. Branch lengths are based on the number of inferred substitutions, as indicated by the scale bar. See Table 1 for abbreviations 


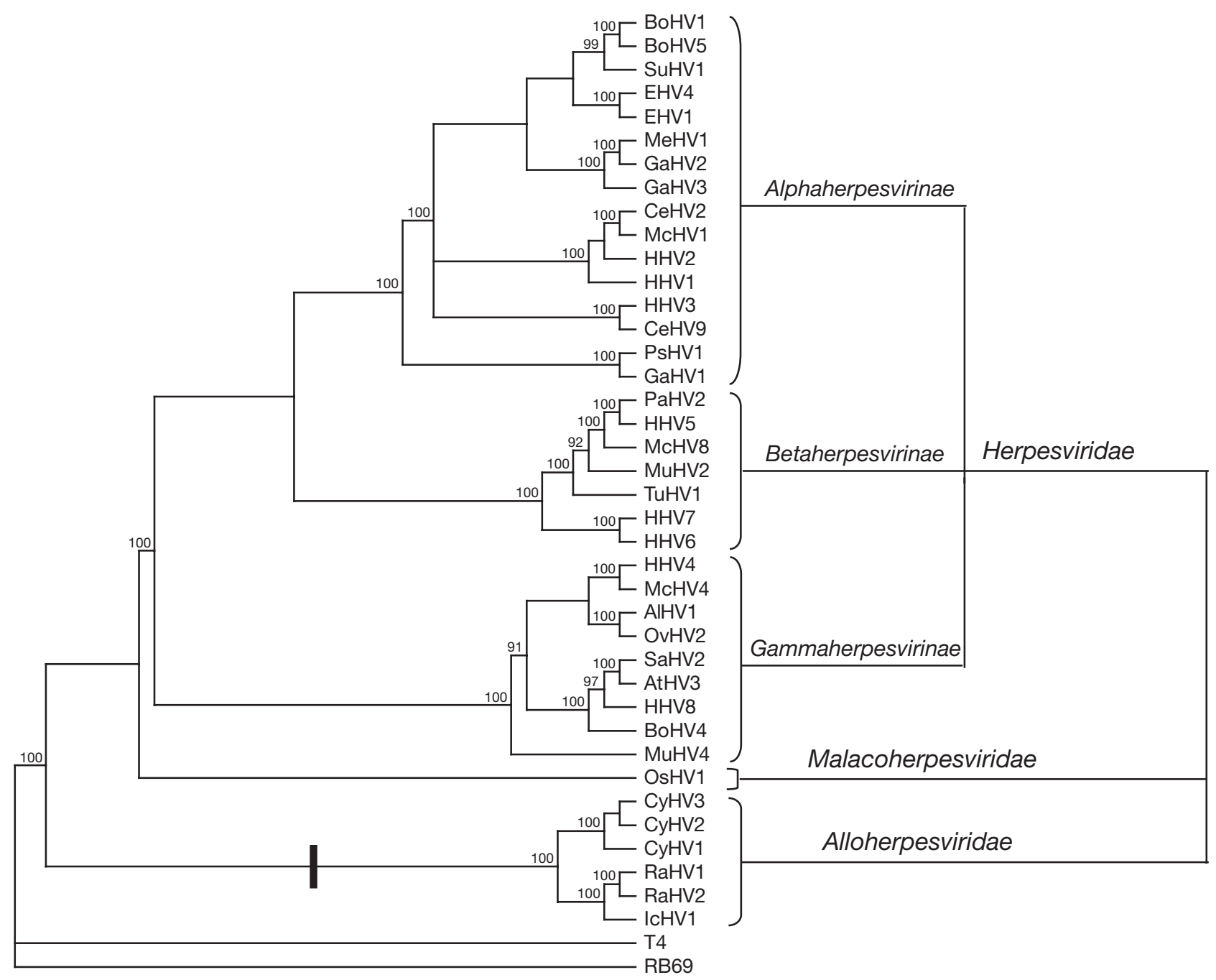

Fig. 4. Cladogram depicting relationships among viruses in the order Herpesvirales, based on the deduced amino acid (AA) sequences of the concatenated 5 conserved regions of the terminase gene (Dataset 41, 283 AA characters including gaps). The Bayesian maximum likelihood tree was rooted using bacteriophages T4 and RB69. Numbers at each node represent the posterior probabilities (values $>90$ shown) of the Bayesian analysis. The vertical bar indicates that the cohesion of the family Alloherpesviridae is also supported by the detectable conservation of at least 13 genes (Aoki et al. 2007). See Tables 1 \& 3 for abbreviations

T4-like bacteriophages, provides the first formally assessed insights into the relationships among all HVs. The findings are in full accord with the recent reclassification of HVs into 3 families. The general lack of detectable sequence relationships among the 3 families implies that future progress in understanding the broad evolutionary relationships among HVs will have to rely on other lines of evidence.

The cladistic (Figs. 1 to 4) and phenetic (Fig. 6, Table 5) analyses facilitated subdivision of the family Alloherpesviridae into 2 sister clades. Clade 1 includes HVs from anguillid and cyprinid hosts, which possess the largest genomes found among HVs, ranging from about $245 \mathrm{kbp}$ in the Dutch and Japanese isolates of AngHV1 (Rijsewijk et al. 2005) to $295 \mathrm{kbp}$ in CyHV3
(Aoki et al. 2007). Our analyses of this clade significantly extend previous preliminary work based upon smaller datasets and incomplete statistical methodologies, and support cohesion of the anguillid and cyprinid HVs (Rijsewijk et al. 2005, Doszpoly et al. 2008). In addition, we note that CyHV3 ORF45 may represent a clade-specific gene, in that a $1500 \mathrm{bp}$ region of a Taiwanese isolate of AngHV1 (Shih et al. 2003; sequence not deposited in a public database) has convincing AA similarity to CyHV3 ORF45 and its counterpart in CyHV1 but not to genes in IcHV1, RaHV1, or RaHV2. Further sequence data are likely to define additional Clade 1 -specific genes. Clade 2 contains the remaining fish HVs and the frog HVs, which appear to possess smaller genomes: IcHV1 has the 


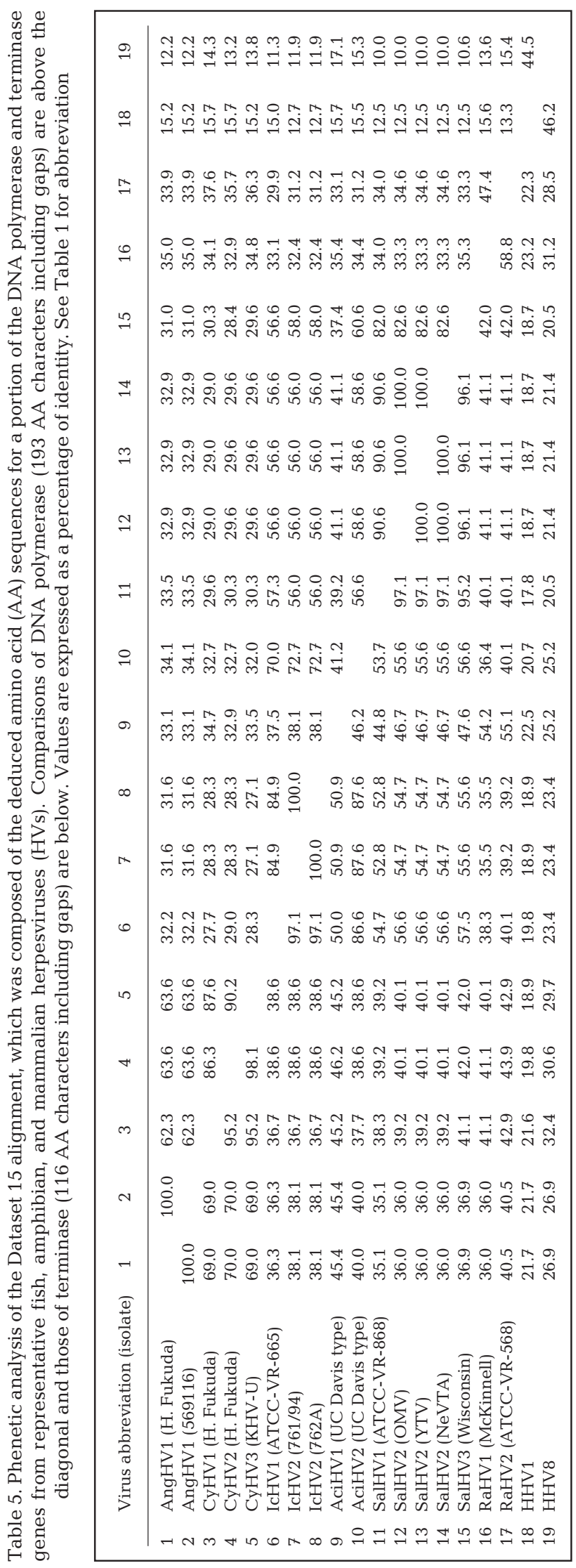

smallest genome at $134 \mathrm{kbp}$, and RaHV2 the largest at $232 \mathrm{kbp}$ (Davison 1992, Davison et al. 2006). Of the 19 genes that are convincingly conserved between IcHV1, RaHV1, and RaHV2, 5 appear not to be conserved in CyHV3 (IcHV1 ORF34, ORF43, ORF44, ORF70, and ORF78) and 1 (ORF53) has a marginal counterpart. Clades 1 and 2 might eventually deserve recognition in the taxonomy of the family Alloherpesviridae, perhaps at the level of subfamily. However, it would be wise to gather additional data before taking this step.

HVs typically exhibit a pattern of cospeciation with their hosts, but exceptions have been noted among the mammalian (McGeoch et al. 2006) and fish HVs (Kelley et al. 2005). Comparison of the phylogeny of fish and amphibian HVs with that of their hosts does not support coevolution between host and virus at deeper nodes of the tree (Fig. 5). For example, the cyprinid and ictalurid fishes are members of the superorder Ostariophysi, and yet the analysis did not reveal a sister species relationship between their respective HVs. The family Acipenseridae (sturgeons) is an ancient fish lineage, and yet the sturgeon HVs (AciHV1 and AciHV2) are not sister taxa, with AciHV2 being the sister group of the ictalurid HVs. The eel HV, AngHV1, also did not show evidence of host cospeciation, as it grouped tightly with the cyprinid HVs. Finally, frogs are the sister group to all of the fish, but frog HVs are sister to only one of the fish HV clades.

If Fig. 5 is an accurate representation of the relationships involved, the lack of observed cospeciation at deeper nodes might reflect existence within an aqueous medium of both the viruses (in relation to ease of interspecies transmission) and those of the hosts (in relation to factors such as extensive migration or international trade, intensive polyculture, and hybridization). Although the analysis revealed overall discordance between HV and host lineages, a degree of coevolution was discernable at the tips of the phylogenetic tree, with the salmonid, ictalurid, ranid, and cyprinid HVs segregating with their respective hosts. AngHV1 groups with the cyprinid HVs in Clade 1, confirming the distinctiveness of these viruses (Sano et al. 1990, Rijsewijk et al. 2005, Waltzek et al. 2005). Moreover, the sequence data confirm serological and molecular evidence that isolates of a HV causing serious disease in eel populations in Europe and Asia represent isolates of AngHV1 (Sano et al. 1990, Chang et al. 2002, Rijsewijk et al. 2005). The cyprinid HVs form a tight clade, CyHV1 and CyHV3 infecting common carp varieties (Cyprinus carpio) and CyHV2 infecting only goldfish Carassius auratus (Hedrick et al. 2004). On the basis of previous findings (Waltzek et al. 2005) and the present study, a strong taxonomic case may be made for the creation of a genus (proposed Cypri- 


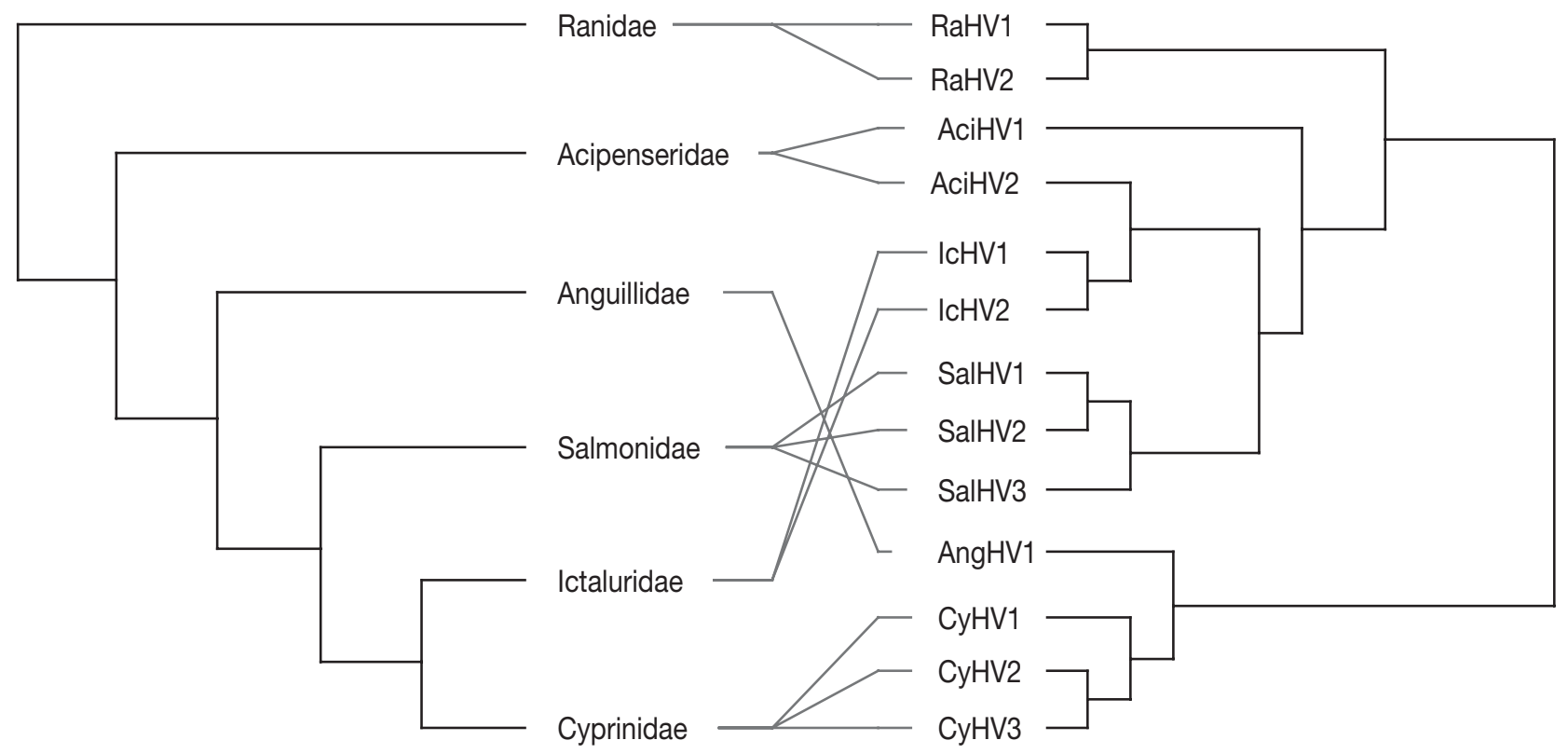

Fig. 5. Tanglegram testing correspondence between the phylogeny of fish and amphibian herpesviruses (HVs) and that of their hosts. See Table 1 for abbreviations

nivirus) to contain these viral species (Cyprinid herpesvirus 1,2 and 3).

In regard to Clade 2, the distinctiveness of the 2 ictalurid (Hedrick et al. 2003), 3 salmonid (Hedrick et al. 1987, Hayashi et al. 1989, McAllister 1993, Yoshimizu et al. 1995, Sung et al. 1996), 2 ranid (Tweedell 1989, Davison et al. 2006), and 2 acipenserid (Hedrick et al. 1991, Watson et al. 1995) HVs has been established previously. The present study supports sister status within these groupings, except for the acipenserid HVs. Both IcHV1 and IcHV2 have been associated with economically important epidemics in their respective ictalurid catfish hosts channel catfish Ictalurus punctatus and black bullhead Ameiurus melas, and the partial sequences of DNA polymerase and terminase analysed in the present study, as well as a similar analysis based solely on the partial DNA polymerase sequence (Doszpoly et al. 2008), demonstrate their affinity. Further evidence for a close relationship between these viruses is suggested by the discovery of a gene encoding a tegument-associated protein in IcHV2 that has a counterpart in IcHV1 (ORF72) but not other HVs (Doszpoly et al. 2008, T. B. Waltzek \& R. P. Hedrick, GenBank accession no. 1162045). Lastly, naturally occurring and experimental infections of channel catfish with IcHV2 result in a disease and mortality similar to that induced by IcHV1 (Hedrick et al. 2003). These findings indicate that IcHV2 should be added to the genus Ictalurivirus. Indeed, a proposal to accomplish this by creating the new species Ameiurine herpesvirus 1 in the genus Ictalurivirus was made recently
(Doszpoly et al. 2008). However, we recommend the species name Ictalurid herpesvirus 2, which is consistent with the formal convention for naming herpesvirus species after the host family (Roizman et al. 1992, Davison et al. 2009). We also support the proposal to add AciHV2 to the genus Ictalurivirus (Doszpoly et al. 2008), and recommend the species name Acipenserid herpesvirus 2. Both SalHV1 (Wolf \& Taylor 1975) and epizootic epitheliotropic disease virus (EEDV) (Bradley et al. 1989, McAllister \& Herman 1989) have been associated with serious epidemics in the USA. In contrast, SalHV2 infects several salmonid species in Japan and has been associated with mortality in young fish and the induction of neoplasia among surviving fish. Our data support the proposal that EEDV represents a distinct salmonid HV, SalHV3 (McAllister 1993). This would prompt the erection of a genus (proposed Salmonivirus) containing these 3 viral species (Salmonid aherpesvirus 1, 2, and 3). The convincing conservation of 40 genes in the 2 frog HVs (Davison et al. 2006) and the results of the present study prompt the establishment of a genus (proposed Batrachovirus) for these viral species (Ranid herpesvirus 1 and 2). Their branching from fish HVs evidently lies deep in the clade, the phylogeny according with the somewhat greater number of genes detectably conserved between the frog $\mathrm{HVs}$ and IcHV1 (19 genes) as compared with the number conserved between IcHV1 and CyHV3 (15 genes). The grouping of AciHV2 isolates from white and shortnose sturgeon with IcHV1, and its more distant relationship 


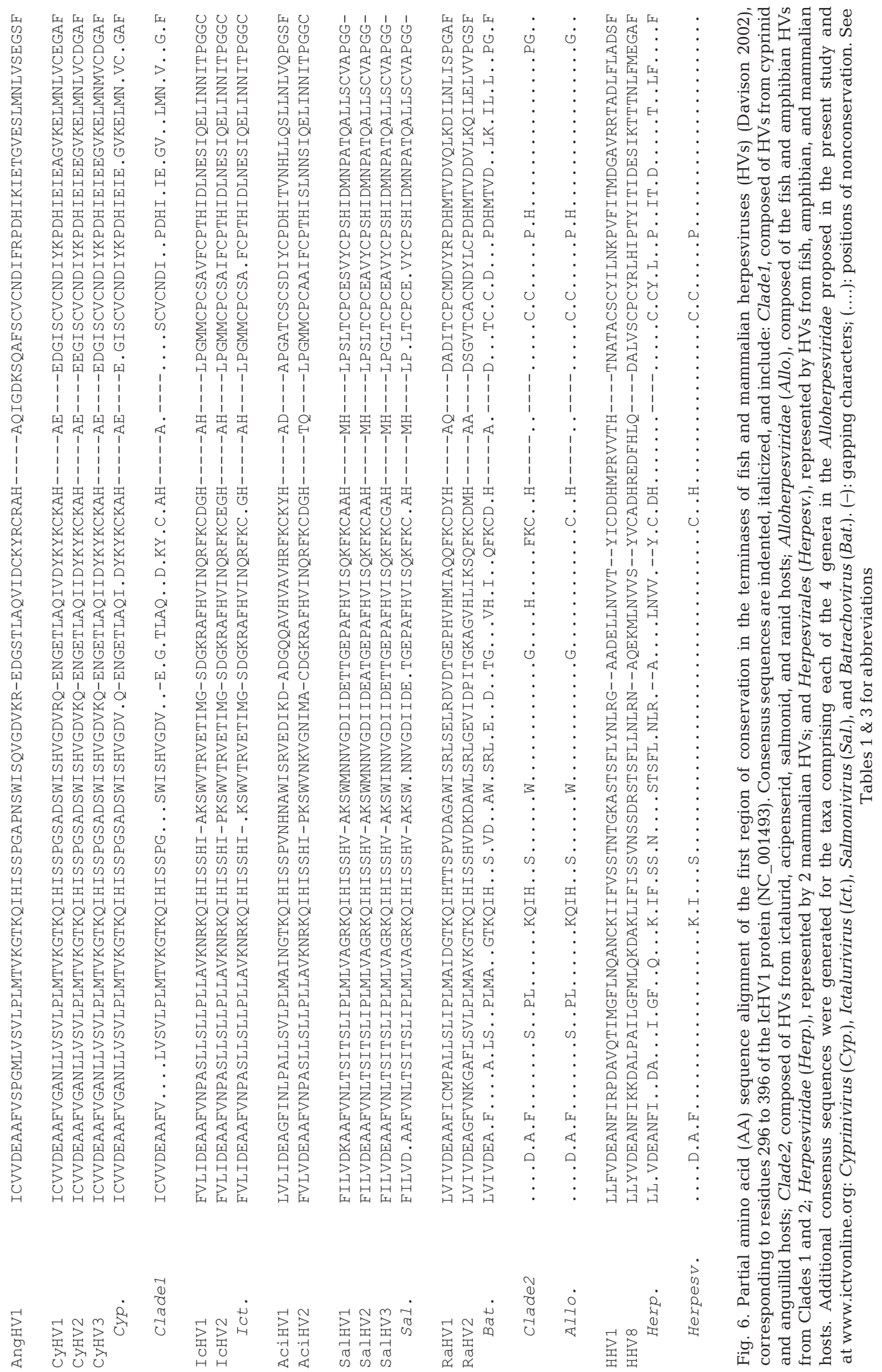


to isolates of AciHV1 from white sturgeon, has been described previously (Kelley et al. 2005, Doszpoly et al. 2008, Kurobe et al. 2008).

In respect of biological properties, the invocation of latent infection as a hallmark of HVs (Roizman \& Pellett 2001) raises the question of whether this is true of the family Alloherpesviridae. The best evidence comes from studies of the Lucké tumor, in which RaHV1 nucleic acid and proteins have been demonstrated in non-infectious, virus-free tumor tissue that, upon temperature manipulation, can yield infectious virus (Biggs 1972, Naegele \& Granoff 1980, Tweedell 1989). Moreover, evidence for a long-term carrier state, which may or may not involve latency, has been described in several fish HVs, including IcHV1 (Wise et al. 1985, Boyle \& Blackwell 1991, Baek \& Boyle 1996, Gray et al. 1999, Thompson et al. 2005), SalHV2 (Gou et al. 1991, Kimura \& Yoshimizu 1998), CyHV1 (Sano et al. 1993), AngHV1 (van Nieuwstadt et al. 2001, Shih 2004), and CyHV3 (Adkison et al. 2005, Bercovier et al. 2005, St-Hilaire et al. 2005). These reports, and others of an anecdotal nature, indicate the existence of long-term infections (perhaps latency) caused by a wide selection of viruses in the family Alloherpesviridae.

Members of the family Alloherpesviridae often induce proliferative epithelial lesions in their respective hosts. HV particles have been observed by electron microscopy and on occasion isolated from neoplastic or hyperplastic epithelial lesions in salmonid, cyprinid, anguillid, osmerid, esocid, silurid, percid, pleuronectid, and acipenserid fishes (Hedrick et al. 1991, Anders \& Yoshimizu 1994, Watson et al. 1995). Neoplastic lesions have been associated with the following fish and amphibian HV infections: several isolates of SalHV2 (i.e. OMV, YTV, and CSTV, but not NeVTA and RKV), RaHV1, and CyHV1, as well as golden ide HV, sheatfish (wels) HV, salmon papillomatosis virus, and smelt papillomatous virus (Tweedell 1989, Anders \& Yoshimizu 1994). Most of these viruses induce papillomas or papilloma-like lesions, except for RaHV1, which is associated with renal adenocarcinoma, and SalHV2, which induces cutaneous carcinomas (Yoshimizu et al. 1987, 1988). Given the phylogeny of the family Alloherpesviridae, and the fact that several viruses induce neoplasia (CyHV1, RaHV1, and SalHV2) or proliferative epithelial lesions (AciHV2 and SalHV3) in their respective hosts, it is likely that the evolution of these biological properties has been complex.

In conclusion, the deduced phylogenetic relationships of 13 fish and amphibian HVs strongly support the monophyly of the family Alloherpesviridae, with 2 major clades evident. The first contains cyprinid and anguillid taxa and the second contains ictalurid, salmonid, acipenserid, and ranid taxa. A pattern of coevolution between virus and host was not supported at deeper nodes but was supported at the tips of the tree. The findings are fully in accord with the recent taxonomic revision of the HVs and will assist in defining additional taxa in the family Alloherpesviridae.

Acknowledgements. We are grateful to S. Yun and T. McDowell for their technical assistance, H. Fukuda for providing the Japanese AngHV-1 isolate, O. L. M. Haenen for providing the Dutch AngHV-1 isolate, P. Q. Spinks for providing phylogenetic guidance throughout this project, and D. J. McGeoch for commenting on a draft of the manuscript. This project was partially supported by NSF DEB 0445453 to MEA, the California Department of Fish and Game, and Grant No. 00132-022008 from the Great Lakes Fisheries Commission.

\section{LITERATURE CITED}

Adkison MA, Gilad O, Hedrick RP (2005) An enzyme linked immunosorbent assay (ELISA) for detection of antibiodies to the koi herpesvirus (KHV) in the serum of koi, Cyprinus carpio. Fish Pathol 40:53-62

Anders K, Moller H (1985) Spawning papillomatosis of smelt (Osmerus eperlanus) from the Elbe estuary. J Fish Dis 8:233-235

Anders K, Yoshimizu M (1994) Role of viruses in the induction of skin tumors and tumor-like proliferations of fish. Dis Aquat Org 19:215-232

Aoki T, Hirono I, Kurokawa K, Fukuda H and others (2007) Genome sequencing of three koi herpesvirus isolates representing the expanding distribution of an emerging disease threatening koi and common carp worldwide. J Virol 81:5058-5065

Baek YS, Boyle JA (1996) Detection of channel catfish virus in adult channel catfish by use of a nested polymerase chain reaction. J Aquat Anim Health 8:97-103

Békési L, Kovacs-Gayer E, Ratz F, Turkovics O (1981) Skin infection of the sheatfish (Silurus glanis L.) caused by a herpes virus. In: Olah J, Molnar K, Jeney Z (eds) Fish, pathogens, and environment in European polyculture. Fisheries Research Institute, Szarvas, p 58-69

Bercovier H, Fishman Y, Nahary R, Sinai S and others (2005) Cloning of the koi herpesvirus (KHV) gene encoding thymidine kinase and its use for a highly sensitive PCR based diagnosis. BMC Microbiol 5:1-9

Bernard J, Mercier A (1993) Sequence of two EcoRI fragments from Salmonis herpesvirus 2 and comparisons with Ictalurid herpesvirus 1. Arch Virol 132:437-442

Biggs PM (1972) Oncogenic herpesvirus infections in animals. J Clin Pathol 25:65-72

Boyle J, Blackwell J (1991) Use of polymerase chain reaction to detect latent channel catfish virus. Am J Vet Res 52: 1965-1968

Bradley T, Chang P, Medina D, McClain J (1989) Epizootic epitheliotropic disease of lake trout (Salvelinus namaycush): history and viral etiology. Dis Aquat Org 7:195-201

Buchanan JS, Madeley CR (1978) Studies on Herpesvirus scophthalmi infection in the turbot Scophthalamus maximus (L.): ultrastructural observations. J Fish Dis 1: 283-295

> Chang PH, Pan YH, Wu CM, Kuo ST, Chung HY (2002) Isolation and characterization of herpesvirus from cultured European eels Anguilla anguilla in Taiwan. Dis Aquat Org 50:111-118 
Davison AJ (1992) Channel catfish virus: a new type of herpesvirus. J Virol 186:9-14

Davison AJ (1998) The genome of salmonid herpesvirus 1. J Virol 72:1974-1982

- Davison AJ (2002) Evolution of the herpesviruses. Vet Microbiol 86:69-88

Davison AJ, Eberle R, Hayward GS, McGeoch DJ and others (2005a) Herpesviridae. In: Fauquet CM, Mayo MA, Maniloff J, Desselberger U, Ball LA (eds) Virus taxonomy. Eighth Report of the International Committee on Taxonomy of Viruses. Elsevier/Academic Press, London, p 193-212

> Davison AJ, Trus BL, Cheng N, Steven AC and others (2005b) A novel class of herpesvirus with bivalve hosts. J Gen Virol 86:41-53

> Davison AJ, Cunningham C, Sauerbier W, McKinnell RG (2006) Genome sequences of two frog herpesviruses. J Gen Virol 87:3509-3514

Davison AJ, Eberle R, Ehler B, Hayward GS and others (2009) The order Herpesvirales. Arch Virol 154:171-177

> Doszpoly A, Kovacs ER, Bovo G, LaPatra SE, Harrach B, Benko $M(2008)$ Molecular confirmation of a new herpesvirus from catfish (Ameiurus melas), by testing the performance of a novel PCR method, designed to target the DNA polymerase gene of alloherpesviruses. Arch Virol 153:2123-2127

- Eaton WD, Wingfield WH, Hedrick RP (1989) Prevalence and experimental transmission of the steelhead herpesvirus in salmonid fishes. Dis Aquat Org 7:23-30

Ehlers B, Lowden S (2004) Novel herpesviruses of Suidae: indicators for a second genogroup of artiodactyls gammaherpesviruses. J Gen Virol 85:857-862

Ehlers B, Ulrich S, Goltz M (1999) Detection of two novel porcine herpesviruses with high similarity to gammaherpsviruses. J Gen Virol 80:971-978

Fijan NN, Wellborne TL Jr, Naftel JP (1970) An acute viral disease of channel catfish. US Department of the Interior, Bureau of Sport Fish and Wildlife, Washington, DC. Technical Paper No. 43

Gou DF, Kubota H, Onuma M, Kodama H (1991) Detection of salmonid herpesvirus (Oncorhynchus masou virus) in fish by southern blot technique. J Vet Med Sci 53:43-48

> Gray WL, Williams RJ, Jordan RL, Griffin B (1999) Detection of channel catfish virus DNA in latently infected catfish. J Gen Virol 80:1817-1822

Hanson LA, Rudis MR, Vasquez-Lee M, Montgomery RD (2006) A broadly applicable method to characterize large DNA viruses and adenoviruses based on the DNA polymerase gene. Virol J 3:28

> Hayashi Y, Kodama T, Mikami T, Izawa V (1989) Serological and genetical relationships of three herpesvirus strains from salmonid fish. Arch Virol 104:163-169

Hedrick RP, Sano T (1989) Herpesviruses of fishes. In: Ahne W, Kurstak E (eds) Viruses of lower vertebrates. SpringerVerlag, Heidelberg, p 161-170

Hedrick RP, McDowell T, Eaton WD, Kimura T, Sano T (1987) Serological relationships of five herpesviruses isolated from salmonid fishes. J Appl Ichthyology 3:87-92

> Hedrick RP, McDowell TS, Groff JM, Yun SC, Wingfield WH (1991) Isolation of an epitheliotropic herpesvirus from white sturgeon Acipenser transmontanus. Dis Aquat Org 11:49-55

> Hedrick RP, Gilad O, Yun S, Spangenberg JV and others (2000) A herpesvirus associated with mass mortality of juvenile and adult koi, a strain of a common carp. J Aquat Anim Health 12:44-57

Hedrick RP, McDowell TS, Gilad O, Adkison M, Bovo G (2003) Systemic herpes-like virus in catfish Ictalurus melas (Italy) differs from Ictalurid herpesvirus 1 (North America).
Dis Aquat Org 55:85-92

Hedrick RP, Gilad O, Yun SC, McDowell TS, Waltzek TB, Kelley GO, Adkison MA (2004) Initial isolation and characterization of a herpes-like virus (KHV) from koi and common carp. Bull Fish Res Agency Suppl 2:1-7

Helfman GS, Collette BB, Facey DE (1997) The diversity of fishes. Blackwell Science, Oxford

Hetrick FM, Hedrick RP (1993) New viruses described in finfish from 1988-1992. Annu Rev Fish Dis 3:187-207

Horiuchi M, Miyazawa M, Nakata M, Iida K (1989) A case of herpesvirus infection on freshwater-reared coho salmon Oncorhynchus kisutch in Japan. Suisanzoshoku 36: 279-305

Hughes J, Kennedy M, Johnson KP, Palma RL, Page RD (2007) Multiple cophylogenetic analyses reveal frequent cospeciation between pelecaniform birds and pectinopygus lice. Syst Biol 56:232-251

Huelsenbeck JP, Ronquist F (2001) MrBayes: Bayesian inference of phylogeny. Bioinformatics 17:754-755

Hyatt AD, Hine PM, Jones HB, Whittington RL and others (1997) Epizootic mortality in the pilchard Sardinops sagax neopilchardus in Australia and New Zealand in 1995. II. Identification of a herpesvirus within the gill epithelium. Dis Aquat Org 28:17-29

Iida Y, Masumura K, Nakai T, Sorimachi M, Matsuda H (1989) A viral disease in larvae and juveniles of the Japanese flounder, Paralichthys olivaceus. J Aquat Anim Health 1: 7-12

> Jung SJ, Miyazaki T (1995) Herpesviral haematopoietic necrosis of goldfish, Carassius auratus (L). J Fish Dis 18: 211-220

Katoh K, Kuma K, Toh H, Miyata T (2005) MAFFT version 5: improvement in accuracy of multiple sequence alignments. Nucleic Acids Res 33:511-518

Kelley GO, Waltzek TB, McDowell TS, Yun SC, LaPatra SE, Hedrick RP (2005) Genetic relationships among herpeslike viruses isolated from sturgeon. J Aquat Anim Health 17:297-303

Kelly RK, Nielsen O, Mitchell SC, Yamamoto T (1983) Characterization of Herpesvirus vitreum isolated from hyperplastic epidermal tissue of walleye, Stizostedion vitreum vitreum (Mitchell). J Fish Dis 6:249-260

Kent ML, Meyers MS (2000) Hepatic lesions in a redstriped rockfish (Sebastes prorigor) suggestive of a herpesvirus infection. Dis Aquat Org 41:237-239

Kimura T, Yoshimizu M (1991) Viral diseases of fish in Japan. Annu Rev Fish Dis 1:67-82

Kimura T, Yoshimizu M (1998) Salmon herpesvirus: OMV, Oncorhynchus masou virus. In: Ahne W, Kurstak E (eds) Viruses of lower vertebrates. Springer-Verlag, Heidelberg, p 171-183

Kimura T, Yoshimizu M, Tanaka M, Sannohe H (1981) Studies on a new virus (OMV) from Oncorhynchus masou-I. Characteristics and pathogenicity. Fish Pathol 15:143-147

$>$ Knopf CW (1998) Evolution of DNA dependent DNA polymerases. Virus Genes 16:47-58

Kumagai AK, Takahashi K, Fukuda H (1994) Epizootics caused by salmonid herpesvirus type 2 infection in maricultured coho salmon. Fish Pathol 29:127-134

Kurobe T, Kelley GO, Waltzek TB, Hedrick RP (2008) Revised phylogenetic relationships among herpesviruses isolated from sturgeons. J Aquat Anim Health 20:96-102

> Lee NS, Kobayashi J, Miyazaki T (1999) Gill filament necrosis in farmed Japanese eels, Anguilla japonica (Temminck \& Schlegel), infected with Herpesvirus anguillae. J Fish Dis 22:457-463

Leibovitz L, Leibovitz SS (1985) A viral dermatitis of the smooth dogfish, Mustelus canis (Mitchell). J Fish Dis 8: 273-279 
Lunger PD, Darlington RW, Granoff A (1965) Cell virus relationships in the Lucké renal adenocarcinoma: an ultastructure study. Ann N Y Acad Sci 126:289-314

Maniloff J, Ackermann HW (1998) Taxonomy of bacterial viruses: establishment of tailed virus genera and the order Caudovirales. Arch Virol 143:2051-2063

McAllister PE (1993) Salmonid fish viruses. In: Stoskoph MK (ed) Fish medicine. WB Saunders, Philadelphia, PA, p 380-408

McAllister PE, Herman RL (1989) Epizootic mortality in hatchery-reared laketrout Salvelinus namaycush caused by a putative virus possibly of the herpesvirus group. Dis Aquat Org 6:113-119

McAllister PE, Lidgerding BC, Herman L, Hoyer C, Hankins J (1985) Viral diseases of fish: first report of carp pox in golden ide (Leuciscus idus) in North America. J Wildl Dis 21:199-204

McArn GE, McCain B, Wellings SR (1978) Skin lesions associated virus in Pacific cod (Gadus macrocephalus) in the Bering Sea. Fed Proc 37:937

> McGeoch DJ, Gatherer D (2005) Integrating reptilian herpesviruses into the family Herpesviridae. J Virol 79: 725-731

McGeoch DJ, Cook S, Dolan A, Jamieson FE, Telford EAR (1995) Molecular phylogeny and evolutionary timescale for the family of mammalian herpesviruses. J Mol Biol 247:443-458

McGeoch DJ, Dolan A, Ralph AC (2000) Toward a comprehensive phylogeny for mammalian and avian herpesvirus. J Virol 74:10401-10406

McGeoch DJ, Gatherer D, Dolan D (2005) On phylogenetic relationships among major lineages of the Gammaherpesvirinae. J Gen Virol 86:307-316

McGeoch DJ, Rixon FJ, Davison AJ (2006) Topics in herpesvirus genomics and evolution. Virus Res 117:90-104

Mellergaard S, Bloch B (1988) Herpesvirus-like particles in angelfish Pterophyllum altum. Dis Aquat Org 5:151-155

Morrison CM, Leggiadro CT, Martell DJ (1996) Visualization of viruses in tumors of rainbow smelt Osmerus mordax. Dis Aquat Org 26:19-23

Naegele RF, Granoff A (1980) The Lucke tumor and its herpesvirus. In: Rapp F (ed) Oncogenic herepsviruses. CRC Press, Boca Raton, FL, p 85-101

Page RDM (1996) TREEVIEW: an application to display phylogenetic trees on personal computers. Comput Appl Biosci 12:357-358

Page RDM, Charleston MA (1998) Trees within trees: phylogeny and historical associations. Trends Ecol Evol 13: 356-359

Page RDM, Hafner MS (1996) Molecular phylogenies and host-parasite cospeciation: gophers and lice as a model system. In: Harvey PH, Leigh Brown AJ, Maynard Smith J, Nee $S$ (eds) New uses for new phylogenies. Oxford University Press, Oxford, p 255-270

Rafferty KA (1965) The cultivation of inclusion-associated viruses from Lucké tumor frogs. Ann N Y Acad Sci 126: $3-21$

Rijsewijk F, Pritz-Verschuren S, Kerkhoff S, Botter A, Willemsen M, van Nieuwstadt $T$, Haenen O (2005) Development of a polymerase chain reaction for the detection of Anguillid herpesvirus DNA in eels based on the herpesvirus DNA polymerase gene. J Virol Methods 124:87-94

Roizman B, Pellett PE (2001) The family of Herpesviridae: a brief introduction. In: Knipe DM, Howley PM (eds) Fields virology, Vol 4. Lippincott, Williams \& Wilkins, Philadelphia, PA, p 2381-2397
Roizman B, Desrosiers RC, Fleckenstein B, Lopez C, Minson AC, Studdert MJ (1992) The family Herpesviridae: an update. Arch Virol 123:425-449

Sano T (1976) Viral diseases of cultured fishes in Japan. Fish Pathol 10:221-226

Sano T, Fukuda H, Okamoto N, Kaneko F (1983) Yamame tumor virus: lethality and oncogenicity. Bull Jpn Soc Sci Fish 49:1159-1163

Sano T, Fukuda H, Furukawa M (1985a) Herpesvirus cyprini: biological and oncogenic properties. Fish Pathol 10: 381-388

Sano T, Fukuda H, Furukawa M, Hosoya H, Moriya Y (1985b) A herpesvirus isolated from carp papilloma in Japan. Fish Shellfish Pathol 32:307-311

Sano M, Fukuda H, Sano T (1990) Isolation and characterization of a new herpesvirus from eel. In: Perkins FO, Cheng TC (eds) Pathology in marine science. Academic Press, San Diego, CA, p 15-31

Sano N, Morikawa M, Hondo R, Sano T (1993) Herpesvirus cyprini: a search for viral genome in infected fish by in situ hybridization. J Fish Dis 16:495-499

Schelkunov IS, Kasaseva TA, Kadoshnikov YUP (1992) Atlantic salmon papillomatosis; visualization of herpeslike particles in skin growths of infected fishes. Bull Eur Assoc Fish Pathol 12:28-31

Schmidt HA, Strimmer K, Vingron M, von Haeseler A (2002) TREE-PUZZLE: maximum likelihood phylogenetic analysis using quartets and parallel computing. Bioinformatics 18:502-504

Shih HH (2004) A polymerase chain reaction for detecting Herpesvirus anguillae in asymptomatic eels. Taiwania 49: $1-6$

Shih HH, Hu CW, Wang CS (2003) Detection of Herpesvirus anguillae infection in eel using in situ hybridization. J Appl Ichthyol 19:99-103

St-Hilaire S, Beevers N, Way K, Le Deuff RM, Martin P, Joiner C (2005) Reactivation of koi herpesvirus infections in common carp Cyprinus carpio. Dis Aquat Org 67:15-23

Sung JT, Yoshimizu M, Nomura T, Ezura Y (1996) Oncorhynchus masou virus: serological relationships among salmonid herpesviruses isolated from kokanee salmon, masu salmon, coho salmon, and rainbow trout. Sci Rep Hokkaido Salmon Hatchery 50:139-144

Suzuki K (1993) A new viral disease on rainbow trout. Shikenkyuwa-Ima 165:1-2 (in Japanese)

Swofford DL (2001) PAUP*. Phylogenetic analysis using parsimony ( ${ }^{*}$ and other methods), version 4. Sinauer Associates, Sunderland, MA

Thompson JD, Higgins DG, Gibson TJ (1994) CLUSTAL W: improving the sensitivity of progressive multiple sequence alignment through sequence weighting, position-specific gap penalties and weight matrix choice. Nucleic Acids Res 22:4673-4680

> Thompson DJ, Khoo LH, Wise DJ, Hanson LA (2005) Evaluation of channel catfish virus latency on fingerling production farms in Mississippi. J Aquat Anim Health 17: 211-215

Tweedell KS (1989) Herpesviruses: interaction with frog renal cells. In: Ahne W, Kurstak E (eds) Viruses of lower vertebrates. Springer-Verlag, Heidelberg, p 13-29

Ueno Y, Kitao T, Chen SN, Aoki T, Kou GH (1992) Characterization of a herpes-like virus isolated from cultured Japanese eels in Taiwan. Fish Pathol 27:7-17

van Nieuwstadt AP, Dijkstra SG, Haenen OLM (2001) Persistence of herpesvirus of eel Herpesvirus anguillae in farmed European eel Anguilla anguilla. Dis Aquat Org 45: 103-107 
Waltzek TB, Kelley GO, Stone DM, Way K and others (2005) Koi herpesvirus represents a third cyprinid herpesvirus (CyHV-3) in the family Herpesviridae. J Gen Virol 86: 1659-1667

Watson LR, Yun SC, Groff JM, Hedrick RP (1995) Characteristics and pathogenicity of a novel herpesvirus isolated from adult and subadult white sturgeon Acipenser transmontanus. Dis Aquat Org 22:199-210

Wibbelt G, Kurth A, Yasmum N, Bannert M, Nagel S, Nitsche A, Ehlers B (2007) Discovery of herpesviruses in bats. J Gen Virol 88:2651-2655

Wise JA, Bowser PR, Boyle J (1985) Detection of channel catfish virus in asymptomatic adult channel catfish, Ictalurus punctatus (Rafinesque). J Fish Dis 8:485-493

Wolf K (1988) Fish viruses and fish viral diseases. Cornell University Press, Ithaca, NY

Editorial responsibility: Mark Crane,

Geelong, Victoria, Australia
Wolf K, Taylor WG (1975) Salmonid herpesviruses: a syncytium-forming agent from rainbow trout. Fish Health News $4: 3$

Yamamoto T, Kelly RK, Nielson O (1983) Epidermal hyperplasia of northern pike (Esox lucius) associated with herpesvirus and C-type particles. Arch Virol 79: 255-272

Yoshimizu M, Tanaka M, Kimura T (1987) Oncorhynchus masou virus (OMV): incidence of tumor development among experimentally infected representative salmonid species. Fish Pathol 22:7-10

Yoshimizu M, Tanaka M, Kimura T (1988) Histopathological study of tumors induced by Oncorhynchus masou virus OMV infection. Fish Pathol 23:133-138

Yoshimizu M, Fukuda H, Sano T, Kimura T (1995) Salmonid herpesvirus 2. Epizootiology and serological relationship. Vet Res 26:486-492

Submitted: September 12, 2008; Accepted: December 11, 2008 Proofs received from author(s): April 16, 2009 